\title{
流域における窒素除去過程としての脱窒の役割
}

\section{楊 宗興*1}

\section{The role of denitrification as a nitrogen sink in river basins}

\author{
Muneoki YOH*1
}

\begin{abstract}
The nitrogen cycling within river basin has recently attracted attention, which is particularly stimulated through estuarine hypoxia problems caused by discharge of nitrogen from land. Proportional relationships have been found between $\mathrm{N}$ load and $\mathrm{N}$ discharge, but the latter is generally far less than the former, indicating possible sinks of nitrogen in the catchment. Although possible processes responsible for such sink are considered as denitrification, retention by plants or soil, concrete evidence has not been given yet. Here, existing researches on denitrification within river basin are reviewed and three relevant works are presented as follows. 1) The $\mathrm{N}$ budget study conducted for agricultural watersheds in hilly region without flat lands showed a 1:1 relationship between $\mathrm{N}$ load and $\mathrm{N}$ discharge, implying the absence of $\mathrm{N}$ sink in these watersheds. 2) Chemical analysis of ground water along an upland-lowland transect in an agricultural area demonstrated the decrease in $\mathrm{NO}_{3}^{-}$ and dissolved oxygen concentration and the increase in relative $\mathrm{N}_{2} / \mathrm{Ar}$ ratio. 3) Denitrification is also appreciable through a number of evidence in the bottom area of hilly forests. Based on the above facts, the importance of denitrification in the underground in lowland for the $\mathrm{N}$ dynamics in river basin is emphasized.
\end{abstract}

Key words: watershed, nitrogen concentration, denitrification, $\mathrm{N}$ input from anthropogenic activities, the loss of nitrogen

\section{1. 背景（流域への窒素負荷}

生物地球化学的な窒素循環に，人間活動は現在 大きく介入するまでになっている。産業革命以 前，新たに固定されて陸域生態系へ持ち込まれる 窒素は生物学的窒素固定による $125 \mathrm{Tg} \mathrm{N} /$ 年で あったのに対し，1990年代前半，人間活動は $157 \mathrm{Tg}$ N/年の新たな窒素インプットを作り出し, 陸域に流入する窒素はトータル $270 \mathrm{Tg} \mathrm{N} /$ 年に達 している (Galloway et al., 2004)。うちわけは, 工業的窒素固定が $100 \mathrm{Tg} \mathrm{N} /$ 年，大豆など豆科植 物の栽培によるものが $32 \mathrm{Tg} \mathrm{N} /$ 年, 化石燃料の
燃焼によるものが $25 \mathrm{Tg} \mathrm{N} /$ 年であり，自然の生 物窒素固定によるものが $107 \mathrm{Tg} \mathrm{N} /$ 年である。 窒素は多様な環境問題に関係しうる元素であ り，こうした窒素循環の増大が様々な環境影響を もたらしている。地下水の硝酸污染，水域の富栄 養化, 温室効果ガス $\mathrm{N}_{2} \mathrm{O}$ 発生量の増加，生物多 様性への影響，海洋の hypoxia 問題等は，こうし た窒素循環の増大の結果，新たに生み出されてい る問題である。

hypoxia とは, 河川河口部に形成される大規模 な貧酸素水塊である。海洋は窒素が制限要因であ るため，陸域から河川を通じて窒素が流れ込むこ

* 1 東京農工大学大学院農学研究院 Institute of Agriculture, Tokyo University of Agriculture and Technology 
とによって富栄養化する。作り出された多量の有 機物が分解することで水中の酸素を消費し大規模 な貧酸素水塊が作り出されているのである。ミシ シッピ川河口部での現象がとくによく知られ (Goolsby, 2000)，この問題については米国環境 保護局，NASA，NOAAをはじめとして多くの Webサイトが開かれる等，非常に関心の持たれ る問題となっている。ミシシッピ川流域での窒素 肥料使用量は 1960 年代頃から増加をつづけてお り，それに伴い河川水中の $\mathrm{NO}_{3}^{-}$濃度の増加が見 られ，また貧酸素水塊の面積が近年増加している (Mitsch et al., 2003)。

\section{2. 流域における窒素の収支}

\section{一負荷された窒素の $75 \%$ 程が流域中に保持}

このような大きな関心を受けて，陸域における 様々な窒素負荷とその後の動態を広域的に評価す る研究が 1990年代から活発に行われてきた。世 界の各河川流域での窒素流出強度を推定しマップ 化したSeitzinger と Kroeze（1998）は，面積あ たりの窒素流出強度がヨーロッパ，東アジア，イ ンドで特に大きいことを示している。広域的な窒 素動態推定の先駆けであるHowarthら（1996） は，大西洋に流れ込む複数の大規模河川につい て，それぞれ流域における単位面積あたりの窒素 負荷と観測される単位面積あたりの流出強度の関 係を検討した。その結果，両者の間に良好な直線 関係があることを示した。流域への窒素負荷は, 河川による窒素の流出を増加させていることがこ れより明らかである。

ただしここで興味深いことに，両者の間の回帰

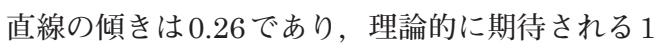
を大きく下回っている。負荷された窒素が全て流 出したなら 1 になるはずでるので，この結果は 流域に揸いてかりの窒素が「保持」されている ことを意味する。その後の研究でもやはり，イン プットに対するアウトプットの比率は 0.16 (Caraco and Cole, 1999), 0.26 (Howarth et al., 2006) と同様の低い值が報告されている。Galloway et al. (2004) の推定でも, 陸域に投入される窒素 $268 \mathrm{Tg} \mathrm{N} /$ 年のうち, その行き先として説明され る量は $93 \mathrm{Tg} \mathrm{N} /$ 年であり, 差し引き $175 \mathrm{Tg} \mathrm{N} /$ 年 の行方が不明となっている。このように，流域に 負荷された窒素のうちかなりの割合がごこかに保 持されているか，あるいは失われている。

このプロセスとしてまず考朰れるのは脱窒で ある。次の項で紹介するように，流域のさまざま な場での脱窒の存在が多くの研究者によって示さ れている。しかし窒素の損失は脱窒のみによって いるか，他のプロセスの寄与はないか，という点 はよくわかっていない。脱窒以外に，植物による 取り込み，土堙の有機態窒素としての保持も，説 明するプロセスとなりうる。森林の成長は $\mathrm{NO}_{3}^{-}$消 失のかなりの割合を説明するとの見積もりもあり (Lowrance et al., 1984; Peterjohn and Correll, 1984），植生による取り込みも $\mathrm{NO}_{3}^{-}$シンクとして 寄与すると考えられている。脱窒は窒素がその場 から完全に損失するのに対し，これらのプロセス の場合は完全な損失ではなく，基本的に一時的な 保持に過ぎないため，流域の窒素収支や海洋への 窒素流出の点での意味は根本的な違いがある。し かし，これらプロセスの相対的重要性についての 信頼できる推定はなく，様々な規模の窒素収支に 打ける最大の不明点となっている（Hill, 1994; Galloway et al., 2004; Howarth et al., 2011)。

\section{3. 流域における脱窒}

流域において見かけ上の窒素の保持が生じる場 としては, 川辺の湿地, 氾濫原, 河畔帯 (riparian zone), 浸出面，ハイポレイックゾーン (河床 間隙水域) がある (Cirmo and McDonnell, 1997)。 地下水中でも脱窒が生ずる（Heaton, 1984; Mariotti et al., 1988; Smith et al., 1991; 齋藤 ・ 小野 寺, 2009)。

なかでも河畔帯については多くの研究が行われ ている (Peterjohn and Correll, 1984; Groffman et al., 1992; Hill, 1994; Clement et al., 2002; Groffman et al., 2009)。河畔帯とは, 河道と斜 
面との間に帯状に，一般に数 $\mathrm{m}$ 数 $10 \mathrm{~m}$ の幅を もって存在する細長い区画（slip）である（Hill， 1994; McClain et al., 2003)。河畔帯が注目され ているのは, 農業地域から流れてきた地下水窒素 の除去が行われる場となっていることが知られて いるからである。流動する地下水がそこを横断す る過程で，窒素濃度の低下が認められる。多くの 場合，河畔帯を通過する間に $\mathrm{NO}_{3}^{-}$の $90 \%$ 以上が 消失する (Hill, 1994; Vidon and Hill, 2006)。 そのホットスポットは段丘と河畔帯との接触部に 数 $\mathrm{m}$ 程の幅で存在する (McClain et al., 2003)。 河畔帯は窒素污染を低減させる窒素シンクとして の機能が期待され，その保全が政府や地方行政体 によっても推奨されている。脱窒は，このような 河畔帯に打ける $\mathrm{NO}_{3}^{-}$消失を生じさせる最も重要 な過程である (Groffman et al., 1992; Hill, 1994; Clement et al., 2002; Groffman et al., 2009)。

一方, 河畔帯以外に, 渓流や河川自体でも脱窒 が生ずる。高い生物活性と脱窒に好適な河床堆積 物という要因により, 渓流や河川は可給態窒素の 重要なシンクと考えられている。このため, 流域 での窒素収支に打いて大きな損失が生じている事 実を説明しょうとする文脈で, 流下中の $\mathrm{NO}_{3}^{-}$の 消失がどのように生じているかを解析した研究が Nature誌に報告されている (Alexander et al., 2000; Mulholland et al., 2008)。

森林でも脱窒が生ずる。Groffman et al. (1989) は土性や排水性の異なる 9 ヶ所の森林土壤につい ての測定で, 脱窒速度は排水性の良い砂質土壤で の $<1 \mathrm{~kg} \mathrm{~N} \mathrm{ha}^{-1} \mathrm{yr}^{-1}$ から排水性の悪い埴壤土で の $40 \mathrm{~kg} \mathrm{~N} \mathrm{ha}{ }^{-1} \mathrm{yr}^{-1}$ まで及んだことを報告して いる。わが国でも森林で脱窒が生ずることを報告 した研究例は多い(木平ら，1997; 石塚・小野 寺, 1997; Koba et al., 1997; Konohira et al., 2001; Osaka et al., 2010)。

Seitzinger et al. (2006) は全球の脱窒量の見積 りを試みる意欲的な論文を発表している。水域は 河口域, 大陸棚, 外洋の酸素極小層について, 陸 域は, 土壤, 地下水, 湖, 河川について, 脱窒量 の見積もりを行っている。土壌，地下水，湖，河
川はそれぞれ $124 \mathrm{Tg} \mathrm{N} /$ 年， $44 \mathrm{Tg} \mathrm{N} /$ 年， $35 \mathrm{Tg} \mathrm{N} /$ 年, $31 \mathrm{Tg} \mathrm{N} /$ 年が見積もられている。脱窒につい ての研究はこれまでケーススタディーに止まりが ちであったのに対し，この論文は脱窒についての 総体としての定量的推定を与えており, 評価すべ き研究と思われる。とはいえ, その推定は, 基本 的に，ある経験的なモデルに則り，さまざまな変 数や係数を割り当てることで行われている。この ため，まだ大きな不確定要因が存在しうることも 理解しておかねばならない。たとえばこの論文 で, 陸域でもっとも大きな值が推定されている土 壤の脱窒については, 加えられた窒素のうち植物 に吸収されなかった部分は $\mathrm{NO}_{3}^{-} に$ 変換され，そ の $25 \%$ が脱窒を受けるとの機械的な仮定で見積 もられている。全球の推定の中でも最も不確実性 が高いのが土壌での脱窒量の推定である(Seitzinger et al., 2006)。

脱窒が空間的, 時間的に局在する性質, ホット スポットやホットモーメントの重要性は一般的に 認識されている。しかしながら, 流域に扔ける重 要な脱窒サイトとされる河畔帯についても, 流域 レベルの窒素収支に果たす役割は未解明である。 河畔帯における窒素除去の効果は, 流域の物質収 支モデルには取り入れられていない (Groffoman et al., 2009)。河畔帯は脱窒が生ずることを示す 報告は多くある一方で, 河畔帯ではどこでも脱窒 が起こるわけではない。ほとんど $\mathrm{NO}_{3}^{-}$の除去が 生じない場合もあり, また, 同じ地点でも測定時 の条件によって窒素のソースになったりシンクに なったりと, $\mathrm{NO}_{3}^{-}$の除去能力には大きな変動性 が存在する (Groffoman et al., 2009)。わが国で も, 水田に窒素浄化機能があることはこれまで知 られているものの, そうした窒素の除去がどこで どのように行われているかの知見は十分ではない (波多野，2005)。このように，フィールドレベ ルでの脱窒研究は研究したサイトについての個別 的記載に止まり，それらを統合し，それにより流 域全体での重要性を見積もるという段階にまでは 至っていない。

森林での脱窒についても，それが行われている 
ことを示す上記のような報告がある一方で，これ まで数多く行われてきた，森林集水域における窒 素収支を推定する研究においては，脱窒はほとん ど無視できるものと見なされてきている（たとえ ば, Campbell et al., 2004)。脱窒がほとんど生 じないのも, 森林生態系の一般的な状況といえ る。すなわち，森林では場合によって確かに脱窒 が起こりうるが，どれほどの脱窒がどのような状 況で生じるかについては，未解明の問題点となっ ている。脱窒の有無に関わると考えられる水文地 形学的要因についての系統だった知見はなく，今 後の重要課題である（Hill, 1994）。

そこで以下の項では，筆者らが森林や農業地域 で得た具体的事例に基づき，脱窒の有無を左右す る地形的要因について議論する。

\section{4. 丘陵地農業集水域における事例}

最初の事例は，標高1000～1400 m の高原に キャベッ畑が広く分布している群馬県嬬恋村を対 象に行った窒素収支の研究である（Yoh, 2012）。 この研究においては, 一般の農業地域と比較して 急な勾配をもち，低平な土地がないこの地の特異 性に着目した。この地形的特性のため, 地下水帯 での脱窒が生じず, この結果, 従来の流域研究と は異なり, 流域への窒素のインプットとアウト プットは等しくなると予想した。ひるがえってこ のことより，流域の物質収支において一般に認め られる窒素の損失は，1）植物の取り込み，2） 土壤有機 $\mathrm{N}$ への不動化，3）土畩の脱窒，4）そ の他のプロセスのためではなく，5）低地での脱 窒による，ことを証明しようとした。1）４）は 共通の条件であり，5）のみが当地に備わってい ないからである。

当地の複数の定点で，6月，8月，10月の 3 回 溪流水を採取した。渓流水採取地点を末端とする 集水域について，その中に占めるキャベッ畑の割 合を見積もり, 溶存無機態窒素濃度がその関数で どれほど説明できるかを検討した。3回の調査の 間での濃度変動は $20 \%$ 以内と比較的安定してお
り，解析にはそれらの平均值を使用した。なお， 渓流水に $\mathrm{NH}_{4}^{+}$は無視できるレベルしか含まれず, 溶存無機態窒素のほとんどは $\mathrm{NO}_{3}^{-}$であった。ほ ぼ全ての地点で有機態窒素が検出され，溶存態全 窒素濃度は $\mathrm{NO}_{3}^{-}$濃度を有意に上回った。解析に は溶存態全窒素濃度を使用した。

キャベッの収穫量ならびにキャベッの窒素含量 から，収穫によって年間に持ちだされる窒素量は $106 \mathrm{kgN} / \mathrm{ha} / \mathrm{yr}$ と計算された。この量を施肥量 (180 kgN/ha/yr) から差し引き, 各集水域内の 農地面積（ha）を掛けて, 流域当たりの窒素負荷 量 $(\mathrm{kgN} / \mathrm{yr})$ を計算した。なお，大気沈着物によ る負荷は施肥量と比較するとわずかであるとして 考慮していない。一方，既存研究（野上，1990; 新井，2004）を参考に年蒸発散量を $700 \mathrm{~mm}$ と仮 定し，年降水量 $(1664 \mathrm{~mm})$ から差し引くこと で流域の年流出量を求めた $\left(0.964 \mathrm{~m}^{3} / \mathrm{m}^{2} / \mathrm{yr}\right)$ 。 これに, 溶存態全窒素濃度 $\left(\mathrm{kgN} / \mathrm{m}^{3}\right)$ と流域面 積 $\left(\mathrm{m}^{2}\right)$ を乗ずることで，各集水域の窒素流出 量 $(\mathrm{kgN} / \mathrm{yr})$ を計算した。

調査を行った複数の流域における窒素負荷量と 窒素流出量の関係を Fig. 1に示す。両者の間には 良好な直線関係が認められ，注目すべきことに， その相関関係の傾きは 1.02 とほぼ 1 となった。河 川による流出量は，各流域について求められた窒 素負荷量とほぼ等しいことになる。このことは, この農業地域では肥料によるインプット, 収穫, 河川流出によって窒素の挙動が説明され, 流域に おける窒素の損失はほとんど存在していないこと を意味する。

流域の規模に差はあるが，この結果は，大きな 窒素損失が認められてきたこれまでの流域研究と は著しく対照的である。高原地においてほとんど 窒素の除去が生じていなかったことは，傾斜地で ある本調查地では，通常の流域で生じている低地 地下部での脱窒が行われていないためと理解でき る。脱窒が生ずるためには，地下水が滞留し，地 下水位がある程度高い一定の水文地形学的状況が 重要であることを示していよう。また，これまで 流域の窒素動態の研究で考えられてきた窒素損失 


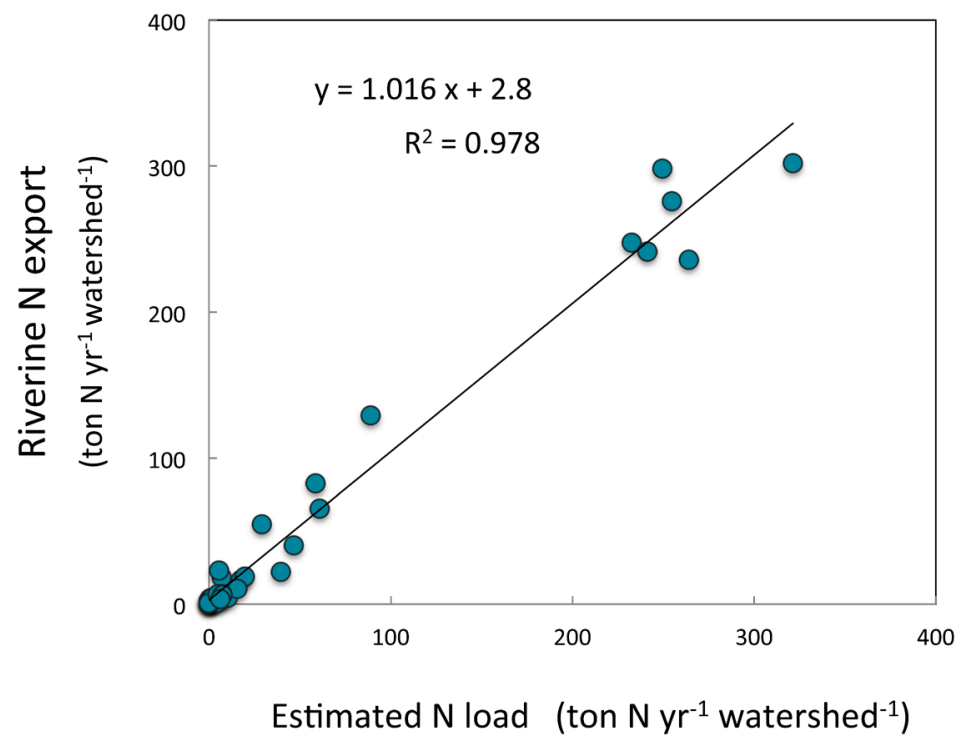

Fig. 1 The relationship between calculated nitrogen loading and estimated riverine export of dissolved nitrogen for watersheds in Tsumagoi highland agricultural region. Different from the nitrogen budgets estimated for other watersheds in general, the $\mathrm{N}$ discharge adequately acconts for the $\mathrm{N}$ load, implying little $\mathrm{N}$ sink in this hilly region. See text for details to calculate both variables.

を生じさせる過程としては，第2項で述べたよう に，土壌や樹木への窒素の取り込みの寄与も予想 されていたが，この結果からは，流域中での窒素 損失には脱窒が主要な役割を果たしていることが 推定される。

\section{5. 低地（lowland）の地下部における 脱窒の証拠}

次に，低地地下部での脱窒の証拠を紹介する。 わが国では畑地・水田の土地利用連鎖において窒 素浄化機能が存在することがよく知られている。 これはたとえば，畑地から流出した $\mathrm{NO}_{3}^{-}$が湛水 状態にある水田等へ流入すると脱窒や取り込みに より消失すること等による。しかし，どこでどの ようなプロセスが起こっているかといった窒素浄 化プロセスの詳細は，必ずしも明確ではない（田 瀬，2003）。また，この浄化能が冒頭に述べた流 域レベルでのみかけの窒素損失と結びつけて論じ られるほどには，窒素動態の体系化は進んでいな い。先に紹介したように，これまで海外の研究に
おいて脱窒の場としては河畔帯や湿地の重要性が 一般に認識されているのに対し, 流域中のそれ以 外の場での知見は限られている。地下水が河川に 到達し流出する前に通過するのが低地であるが, このような低地の帯水層で脱窒が行われている可 能性があり，低地の地下部に打ける脱窒の役割に ついて検討した。

農村地域の「台地部」〜低地部」の系列を設定 し，これに沿って複数地点で地下水を採取し地下 水分析を行った。調査地は千葉県鎌ヶ谷市であ り，台地部は果樹 (梨園) の他，だいこん，ねぎ などが栽培され，低地部は水田としての利用が多 い。各民家では，地下水をポンプでくみ上げ，蛇 口から取り出せるようにしている。その蛇口から 地下水を採取した。分析はイオン成分の他, Yoh et al.（1998）を改変した気液平衡法（新谷, 2006）により溶存気体を測定した。

結果を Fig. 2 に示す。地下水の $\mathrm{NO}_{3}^{-}$濃度は, 台 地部では 930-2000 $\mu \mathrm{mol} / \mathrm{L} の$ 範囲であったのに対

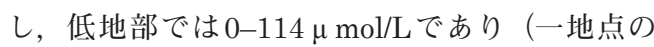
み $650 \mu \mathrm{mol} / \mathrm{L})$, 明らかな低下を示した。 $\mathrm{NO}_{3}^{-} /$ 

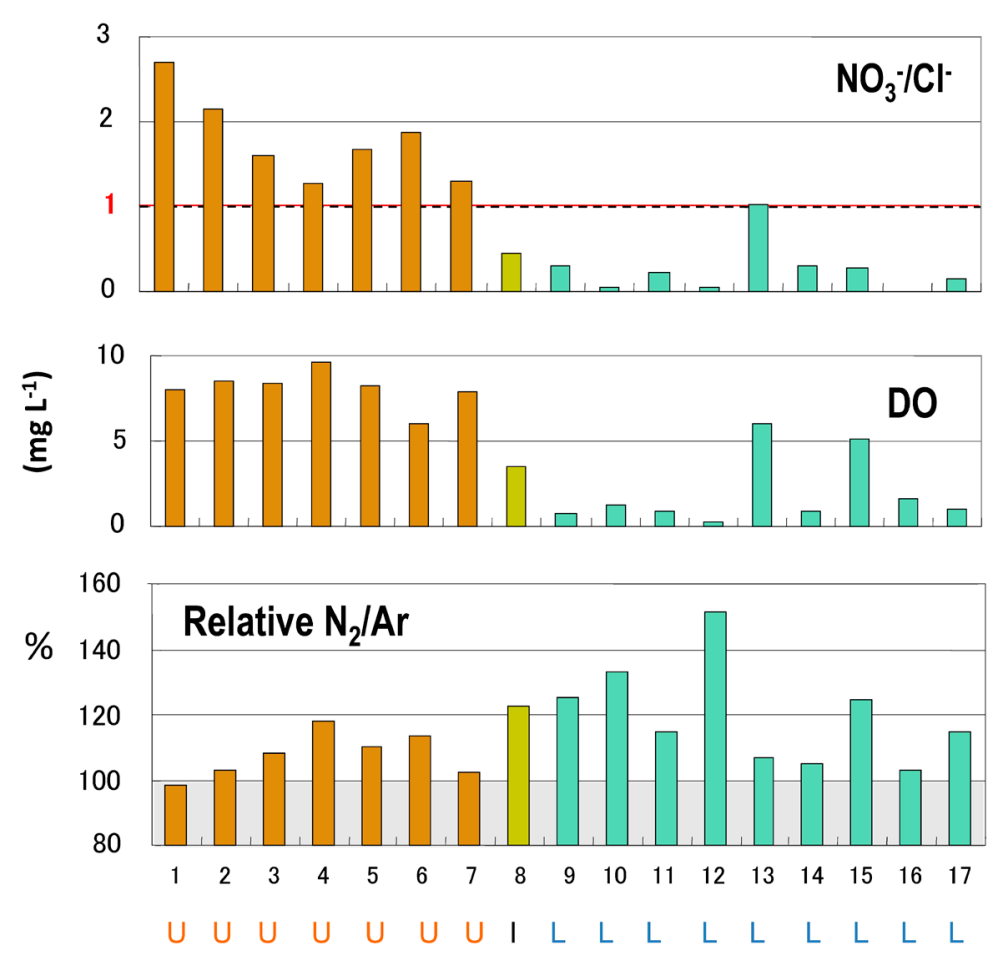

Fig. 2 Change in $\mathrm{NO}_{3}^{-} / \mathrm{Cl}^{-}$ratio (top), dissolved oxygen concentration (middle) and relative $\mathrm{N}_{2} / \mathrm{Ar}$ ratio in dissolved gases (bottom) along a upland-lowland transect in agricultural region in Kamagaya, Chiba prefecture. Relative $\mathrm{N}_{2} / \mathrm{Ar}$ ratio represents the percentage of measured $\mathrm{N}_{2} / \mathrm{Ar}$ ratio relative to the theoretical value calculated from in situ temperatures. U, L and I in the figure denote upland sites, lowland sites and intermediate site, respectively.

$\mathrm{Cl}^{-}$比も，台地部に比べ低地部で顕著に低下して おり, $\mathrm{NO}_{3}^{-}$の現象が単なる希釈によるものでない ことを示している。台地部の地下水は 6〜 $10 \mathrm{mg} / \mathrm{L}$ と飽和濃度に近い溶存酸素を含んでいたが, 低地 部では溶存酸素濃度が顕著に低下しており, ほと んど消失している例が多く見られる。溶存ガス分 析の結果，地下水の $\mathrm{N}_{2} / \mathrm{Ar}$ 比はほとんどの井戸で 大気平衡值を上回っていたが，とくに低地部で顕 著であり， $\mathrm{N}_{2}$ を過剩に含んでいることが判明し た。この結果は, 低地部の地下水中では溶存酸素 の低下が生じ，そのために脱窒が活発に行われて $\mathrm{NO}_{3}^{-}$の除去に寄与していることを示している。

これら低地部の地下水は，直上部から鉛直的に 涵養されるだけでなく，その地点を末端とする 「集水域」全体から水平方向の地下水流動によっ て涵養されたものと考えられる。すなわち，段丘 上の地下に存在していた $\mathrm{NO}_{3}^{-}$濃度の高い地下水
の多くは，河川へ流出する前に，脱窒の活発な低 地地下水帯を通過するものと推定される。このこ とからすると, $\mathrm{NO}_{3}^{-} / \mathrm{Cl}^{-}$比の変化は, 低地部での 脱窒による $\mathrm{NO}_{3}^{-}$除去の程度を反映しているとみ なすことが可能であろう。 $\mathrm{NO}_{3}^{-} / \mathrm{Cl}^{-}$比は台地部で の平均 1.7 から低地部での平均 0.3 へと $82 \%$ の低 下を示している。調査したこのフィールドの場 合，河川に流出する前に $\mathrm{NO}_{3}^{-}$は $18 \%$ に減少して いる計算になり，これは，流域レベルでこれまで に測定されているみかけの窒素損失の割合とほぼ 一致する。低地部の地下水帯は高い地下水位のた めに溶存酸素濃度が低下して脱窒に好適な条件を 提供し，流域に負荷された窒素を除去する重要な 場になっている可能性がある。高 $\mathrm{NO}_{3}^{-}$濃度の台 地部地下水が低地の地下部を流動する間に脱窒に より $\mathrm{NO}_{3}^{-}$の消費が生ずることは, 最近, Eguchi ら（2009）によっても定量的に示されている。 


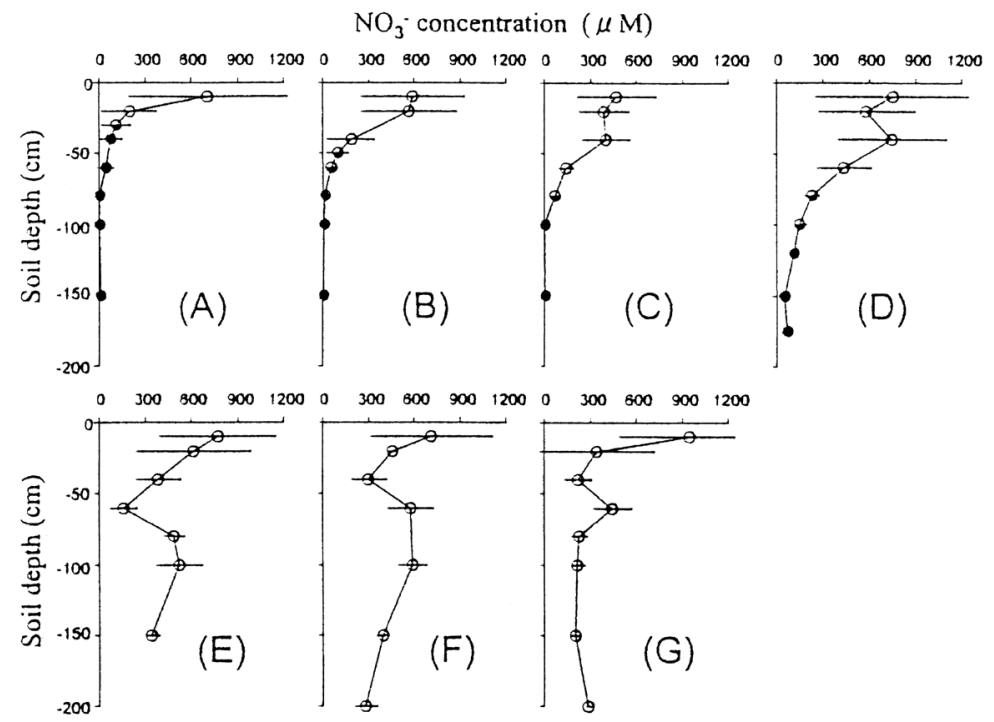

Fig. 3 Change in soil $\mathrm{NO}_{3}^{-}$profile along a topological sequence from bottom (A) to slope $(\mathrm{G})$ in a forested watershed. The sites (A), (B), (C) and (D) are bottom area, where deep horizon was observed to be water-saturated as designated by closed circle.

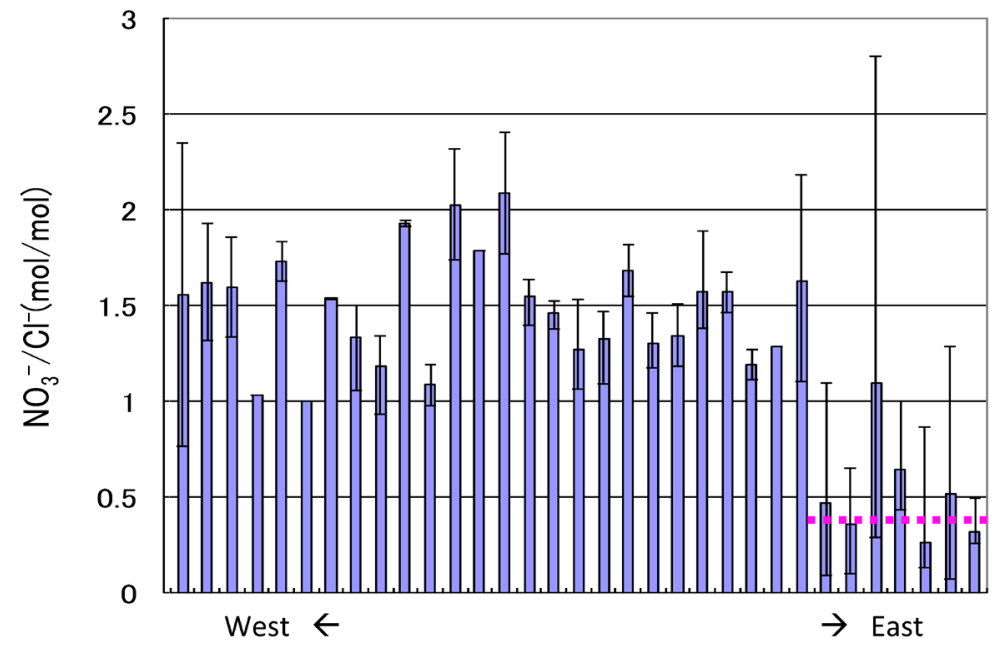

Fig. 4 Regional distribution of $\mathrm{NO}_{3}^{-} / \mathrm{Cl}^{-}$ratio in stream water along a west-east transect in the Tama River system. Note that the ratios distictly drop in the eastward streams (as denoted by dotted line), where hilly area is distributed.

\section{6. 丘陵地の谷底部}

森林は急峻な山地の場合もあれば，緩傾斜の場 合もある。丘陵地は山地より起伏が小さく，その 谷部は比較的平坦である。船底型と呼ばれる地形
を形成し, しばしば谷地と呼ばれる過湿な平坦部 を持つ。こうした丘陵地の谷底部は一つの典型的 な脱窒サイトになっているようである。

東京都八王子市に位置する丘陵地の森林集水域 に扔いて，谷部では土銥深部の $\mathrm{NO}_{3}^{-}$は消失して 
いることが示されている (Fig. 3) (Konohira et al., 2001)。斜面部〜谷底部の系列において比較 した結果，斜面部では土㖶深部でも $\mathrm{NO}_{3}^{-}$が存在 するのに対し，下部 4 地点では飽和帯が存在する $50 \mathrm{~cm}$ か $150 \mathrm{~cm}$ 以深で $\mathrm{NO}_{3}^{-}$が完全に消失す る。このような深部の土堙では，アセチレン阻害 法による脱窒活性が検出され，また $\mathrm{NO}_{3}^{-} の \delta^{15} \mathrm{~N}$ が上昇していることからも，脱窒が証拠立てられ ている（木平ら，1997）。

多摩川中～上流部の森林溪流水の $\mathrm{NO}_{3}^{-} / \mathrm{Cl}^{-}$比 を東西の地理的位置にしたがって並べると，最も 東部の東京近郊で, $\mathrm{NO}_{3}^{-} / \mathrm{Cl}^{-}$比の明らかな低下 が観察される (Fig. 4)。これらの渓流は谷地を持 つ丘陵地域にちょうど対応する。このような渓流 では, $\mathrm{NO}_{3}^{-} / \mathrm{Cl}^{-}$比が低下寸るだけでなく, $\mathrm{SO}_{4}^{2-}$ 濃度もその上流部より低下し，また $\mathrm{Mn}^{2+}$ や $\mathrm{NH}_{4}^{+}$ が検出されるという還元過程の存在を示す特徴も 見られる。丘陵地の集水域では，飽和帯が存在す る谷底部に還元的条件が発達し, 流出する $\mathrm{NO}_{3}^{-}$ の脱窒による消費が行われる場になっていると見 ることができる（楊ら，2004）。

\section{7. 結論と摘要}

先に述べたように，これまで流域における窒素 の損失がどこでどのように行われているかの知見 は十分ではなかった。これに対し，本稿で紹介し た結果は，低地地下部の重要性を示している。こ の場合の低地とは，横断的な側面だけでなく縦断 的な側面の $2 つ の$ 意味を考えることができる。河 川の縦断面は指数関数で近似され（高山，1986）, 下流部で勾配が減少するのは陸面の一般的特性だ からである。これまでしばしば報告されている河 川流域に打ける窒素投入量に比べて窒素流出量が 大きく下回る現象は，主にこのような場での脱窒 による可能性が高いと言える。現在まだデータは 十分ではないが，今後，さまざまな立地条件の知 見を蓄積し，水文地形学的要因についての体系 化，系統的な整理を進めていくことが今後の重要 な課題と思われる。

\section{引用文献}

新井 正（2004）：地域分析のための熱・水収支 水文学, 古今書院.

新谷 渉 (2006)：下総台地の田園地域における 地下水の水質形成過程と脱窒の可能性の検討, 東京農工大学農学部環境資源科学科卒業論文.

石塚成宏・小野寺真一 (1997)： $\delta^{15} \mathrm{~N}$ 值による平 地林浅層地下水中に打ける脱窒の検証: 茨城県 南西部常総台地の例, 日本土䁃肥料学雜誌, $68,1-7$.

木平英一，楊 宗興，戸田任重，八木一行，窪田 順平，塚本良則（1997）：森林流域谷底部土壤 の脱窒作用 : $\mathrm{NO}_{3}^{-}-\mathrm{N}$ 窒素安定同位体比による 解析, 日本林学会誌, 79, 83-88.

齋藤光代・小野寺真一 (2009)：沿岸農業流域に おける地下水による硝酸性窒素流出の季節変動 特性, 陸水学雑誌， 70, 141-151.

高山茂美（1986）：理科年表読本，川の博物誌, 丸善.

田瀬則雄（2003）：硝酸・亜硝酸性窒素による水 質污染の現状と動向，水環境学会誌， 26, 546550 .

野上道男（1990）：暖かさの指数と流域蒸発散量 一気候值メッシュデータによる解析, 地学雜 誌，99，682-694.

波多野隆介（2005）：河川への窒素流出測定によ る流域の窒素循環評価，波多野·犬伏編，続· 環境負荷を予測する，43-59，博友社.

楊 宗興・木平英一・武重祐二・杉山浩二 · 三宅 義則 $(2004)$ : 溪流水の $\mathrm{NO}_{3}{ }^{-}$濃度と森林の窒 素飽和, 地球環境, 9, 29-40.

Alexander, R. B., R. A. Smith, and G. E. Schwarz (2000): Effect of stream channel size on the delivery of nitrogen to the Gulf of Mexico, Nature, 403, 758-761.

Campbell, J. L., J. W. Hornbeck, M. J. Mitchell, M. B. Adams, M. S. Castro, C. T. Driscoll, J. S. Kahl, J. N. Kochenderfer, G. E. Likens, and J. A. Lynch (2004): Input-output bud- 
gets of inorganic nitrogen for 24 forest water-

sheds in the northeastern United States: a review, Water, Air, \& Soil Pollution, 151, 373-396.

Caraco, N. and J. Cole (1999): Regional scale export of C, N, P and sediment: what river data tell us about key controlling variables, Biogeochemistry in complex landscapes, Wiley, 233-244.

Cirmo, C. P., and J. J. McDonnell (1997): Linking the hydrologic and biogeochemical controls of nitrogen transport in near-stream zones of temperate-forested catchments: a review, Journal of Hydrology, 199, 88-120.

Clément, J.-C., G. Pinay, and P. Marmonier (2002): Seasonal dynamics of denitrification along topohydrosequences in three different riparian wetlands, Journal of Environmental Quality, 31, 1025-1037.

Eguchi, S., Y. Nakajima, S. Yabusaki, M. Kasuya, H. Shibayama, A. Tsunekawa, K. Imai (2009): Denitrification during vertical upwelling at an alluvium-diluvium interface below the upland perimeter of a riparian paddy, Journal of Environmental Quality., 38, 2198-2209.

Galloway, J. N., F. J. Dentener, D. G. Capone, E. W. Boyer, R. W. Howarth, S. P. Seitzinger, G. P. Asner, C. Cleveland, P. Green, and E. Holland (2004): Nitrogen cycles: past, present, and future, Biogeochemistry, 70, 153226.

Goolsby, D. A. (2000): Flow of nitrogen into Mississippi Basin believed to cause Gulf hypoxia, Earth in Space, 13, 6-10.

Groffman, P. M., and J. M. Tiedje (1989): Denitrification in north temperate forest soils: spatial and temporal patterns at the landscape and seasonal scales, Soil Biology and Biochemistry, 21, 613-620.
Groffman, P. M., A. J. Gold, and R. C. Simmons (1992): Nitrate dynamics in riparian forests: microbial studies, Journal of Environmental Quality, 21, 666-671.

Groffman, P. M., K. Butterbach-Bahl, R. W. Fulweiler, A. J. Gold, J. L. Morse, E. K. Stander, C. Tague, C. Tonitto, and P. Vidon (2009): Challenges to incorporating spatially and temporally explicit phenomena (hotspots and hot moments) in denitrification models, Biogeochemistry, 93, 49-77.

Heaton, T. (1984): Sources of the nitrate in phreatic groundwater in the western Kalahari, Journal of Hydrology, 67, 249-259.

Hill, A. R. (1996): Nitrate removal in stream riparian zones, Journal of Environmental Quality, 25, 743-755.

Howarth, R. W., G. Billen, D. Swaney, A. Townsend, N. Jaworski, K. Lajtha, J. A. Downing, R. Elmgren, N. Caraco, T. Jordan, F. Berendse, J. Freney, V. Kudeyarov, P. Murdoch, and Z. Zhu (1996): Regional nitrogen budgets and riverine $\mathrm{N} \& \mathrm{P}$ fluxes for the drainages to the North Atlantic Ocean: Natural and human influences, Biogeochemistry, 75, 75-139.

Howarth, R., D. Swaney, E. Boyer, R. Marino, N. Jaworski, and C. Goodale (2006): The influence of climate on average nitrogen export from large watersheds in the Northeastern United States, Biogeochemistry, 79, 163-186.

Howarth, R., D. Swaney, G. Billen, J. Garnier, B. Hong, C. Humborg, P. Johnes, C.-M. Morth, and R. Marino (2011): Nitrogen fluxes from the landscape are controlled by net anthropogenic nitrogen inputs and by climate, Frontiers in Ecology and the Environment, 10, 37-43.

Koba, K., N. Tokuchi, E. Wada, T. Nakajima, and G. Iwatsubo (1997): Intermittent deni- 
trification: The application of a ${ }^{15} \mathrm{~N}$ natural abundance method to a forested ecosystem, Geochimica et Cosmochimica Acta, 61, 50435050.

Konohira, E., M. Yoh, J. Kubota, K. Yagi, and H. Akiyama (2001): Effects of riparian denitrification on stream nitrate-evidence from isotope analysis and extreme nitrate leaching during rainfall, Water, Air, \& Soil Pollution, 130, 667-672.

Lowrance, R., R. Todd, J. Fail, O. Hendrickson, R. Leonard, and L. Asmussen (1984) : Riparian forests as nutrient filters in agricultural watersheds, BioScience, 34, 374-377.

Mariotti, A., A. Landreau, and B. Simon (1988): ${ }^{15} \mathrm{~N}$ isotope biogeochemistry and natural denitrification process in groundwater: Application to the chalk aquifer of northern France, Geochimica et Cosmochimica Acta, 52, 1869-1878.

McClain, M. E., E. W. Boyer, C. L. Dent, S. E. Gergel, N. B. Grimm, P. M. Groffman, S. C. Hart, J. W. Harvey, C. A. Johnston, and E. Mayorga (2003): Biogeochemical hot spots and hot moments at the interface of terrestrial and aquatic ecosystems, Ecosystems, 6, 301-312.

Mitsch, W. J., J. W. Day, Jr., J. W. Gilliam, P. M. Groffman, D. L. Hey, G. W. Randall, and N. Wang (2001): Reducing Nitrogen Loading to the Gulf of Mexico from the Mississippi River Basin: Strategies to Counter a Persistent Ecological Problem, BioScience, 51, 373388.

Mulholland, P., A. Helton, G. Poole, R. Hall, S. Hamilton, B. Peterson, J. Tank, L. Ashkenas, L. Cooper, and C. Dahm (2008): Stream denitrification across biomes and its response to anthropogenic nitrate loading, Nature, 452, 202-205.
Osaka, K. i., N. Ohte, K. Koba, C. Yoshimizu, M. Katsuyama, M. Tani, I. Tayasu, and T. Nagata (2010): Hydrological influences on spatiotemporal variations of $\delta^{15} \mathrm{~N}$ and $\delta^{18} \mathrm{O}$ of nitrate in a forested headwater catchment in central Japan: Denitrification plays a critical role in groundwater, Journal of Geophysical Research: Biogeosciences (2005-2012), 115 (G2) .

Peterjohn, W. T. and D. L., Correll (1984): Nutrient dynamics in an agricultural watershed, Ecology, 65, 1466-75.

Schlesinger, W. H. (2009): On the fate of anthropogenic nitrogen, Proceedings of the $\mathrm{Na}$ tional Academy of Sciences, 106, 203-208.

Seitzinger, S. P. and C. Kroeze (1998): Global distribution of nitrous oxide production and $\mathrm{N}$ inputs in freshwater and coastal marine ecosystems, Global Biogeochemical Cycles, 12, 93-113.

Seitzinger, S., J. A. Harrison, J. Bohlke, A. Bouwman, R. Lowrance, B. Peterson, C. Tobias, and G. V. Drecht (2006) : Denitrification across landscapes and waterscapes: a synthesis, Ecological Applications, 16, 2064-2090.

Smith, R. L., B. L. Howes, and J. H. Duff (1991): Denitrification in nitrate-contaminated groundwater: Occurrence in steep vertical geochemical gradients, Geochimica et Cosmochimica Acta, 55, 1815-1825.

Vidon, P. and A. R. Hill (2006): A landscapebased approach to estimate riparian hydrological and nitrate removal functions, Journal of the American Water Resources Association., 42, 1099-1112.

Yoh, M. (2012): Possible Nitrogen Removal through Denitrification in the Watershed Scale. JIFS, 9, 51-55.

Yoh, M., M. Takeuchi, and H. Toda (1998): Simultaneous measurement of $\mathrm{N}_{2}, \mathrm{O}_{2}, \mathrm{Ar}, \mathrm{CO}_{2}$, 
$\mathrm{CH}_{4}, \mathrm{H}_{2}$ and $\mathrm{CO}$ in aqueous and gaseous samples: a detection of $\mathrm{N}_{2} / \mathrm{Ar}$ shifts in environments, Japanese Journal of Limnology, 59, 147-157.
(原稿受付 : 2014 年 3 月 13 日)

(原稿受理：2014年 10 月 27 日)

この論文に対する「討論」を 2015年5月 31 日 まで受け付けます。

\title{
流域における窒素除去過程としての脱窒の役割
}

\author{
楊 宗興
}

\author{
要旨
}

近年，陸域への窒素の負荷に起因した海域の貧酸素水塊形成の問題等から，窒 素の流域レベルの動態に関心が持たれている。陸域に負荷される窒素と流出する 窒素の間には比例関係が認められている。しかし，後者は前者を一般に大きく下 回り，流域には窒素の大きなシンクが存在する。その損失過程としては脱窒や植 物・土堙への吸収などが考えられているが，詳細は不明である。平野部のない高 原農業地域で集水域ごとの窒素収支を検討すると, 負荷窒素と流出窒素の関係は これまでの研究例と異なりほぼ $1: 1$ であり，窒素の損失は存在しなかった。台 地部一低地部卜ランゼクトに沿って地下水を分析すると, 低地部で $\mathrm{NO}_{3}^{-}$や溶存酸 素濃度の減少，相対 $\mathrm{N}_{2} / \mathrm{Ar}$ 比の上昇が認められる。さらに，丘陵地谷底部土堙深 部でも脱窒を示すさまざまな証拠がある。以上の事実から，流域での窒素の動態 に扔いて低平地の地下部での脱窒が一般に重要である可能性を提唱する。

キーワード : 流域, 窒素濃度, 脱窒, 人間活動による窒素インプット, 窒素の損失 